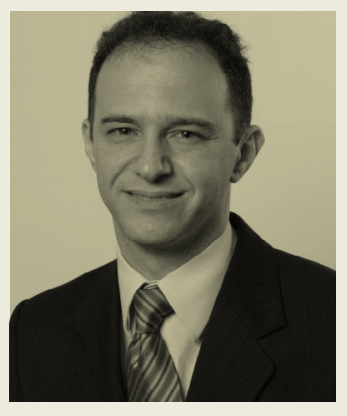

\title{
PROPÓSITO: UM CONCEITO PARA PREENCHER VAZIOS
}

No mundo dos negócios, vários conceitos já viraram trending topics. Citando apenas alguns: produção em massa, qualidade total, competitividade, responsabilidade corporativa, empowerment e sustentabilidade. Mas, ultimamente, um termo que vem ganhando bastante força é: propósito.

As pessoas estão buscando um propósito de vida, os profissionais, um propósito de carreira e as empresas, um propósito em suas ações. Isso reflete em várias tendências voltadas a esse foco. No capitalismo consciente, o propósito é o primeiro pilar; para o Sistema B, é um elemento central; para os negócios de impacto, é o ponto de partida.

Mas será que esse propósito é só mais um trending topic ou chegou para ficar? Isso vai depender de como as pessoas, as empresas e a sociedade vão se apropriar dessa visão.

Nas empresas, para que o propósito não seja um conceito vazio, superficial, é importante que haja pragmatismo em suas ações e uma mudança efetiva no modelo de negócios. Algumas grandes empresas têm desenvolvido projetos que alinham o benefício social ao retorno financeiro em uma perspectiva de valor compartilhado. Nessa visão, o impacto social gerado e o propósito estão relacionados às atividades core das corporações, sendo que um impulsiona o outro.

Recentemente, a ideia de negócios sociais e de negócios de impacto, organizações que têm em seu
DNA o objetivo de afetar positivamente a sociedade, tem ganhado força. Em geral, nos negócios de impacto, o propósito é acompanhado de uma teoria de mudança que deixa claro qual impacto social e/ou ambiental o negócio almeja gerar e como isso pode ser realizado.

No Brasil e no mundo, o ecossistema de negócios de impacto tem crescido bastante. Nos últimos anos, a quantidade e o tipo de organizações que apoiam esse ecossistema multiplicaram. Da mesma forma, o número e a relevância desses negócios cresceram exponencialmente. Diferentemente das organizações não governamentais (ONGs), os negócios de impacto não dependem de doações e filantropia para existir.

Apesar de não ser um conceito fechado, os negócios de impacto aparecem como uma ótima alternativa para uma nova geração de empreendedores que quer fazer o bem (propósito de vida) e ganhar dinheiro, quebrando o suposto paradoxo de que não é possível conseguir ambos ao mesmo tempo.

Nos países emergentes e no Brasil, especificamente, são muitos os buracos estruturais e as necessidades sociais a serem mitigadas. O governo e o terceiro setor têm seus limites. Assim, os negócios de impacto têm o potencial de preencher os vazios sistêmicos e utilizar os mecanismos de mercado para criar uma sociedade mais justa, menos desigual e com mais propósito. 